\title{
INFLUENCE OF VARIABLES ON CENTRIFUGE-FLOTATION TECHNIQUE FOR RECOVERY OF Toxocara canis EGGS FROM SOIL
}

Vamilton Alvares SANTARÉM(1), Luciana Puga MAGOTI(2) \& Tathiana Dias SICHIERI(3)

\begin{abstract}
SUMMARY
The purpose of this study was to evaluate the influence of variables in a flotation technique for the recovery of Toxocara canis eggs from soil. The trials were done under standardized conditions on one gram of previously sterilized soil samples contaminated with 200 eggs of T. canis. The following variables were evaluated in serial steps: sieving; type of wash; time of stirring; resuspension of sediment; solution flotation. Centrifuge-flotation in sodium nitrate $\left(\mathrm{d}=1.20 \mathrm{~g} / \mathrm{cm}^{3}\right)$ was adopted as an initial technique, using Tween $80(0.2 \%)$ and decinormal sodium hydroxide as solutions for washing the samples. Ten tests were done to compare the variables, using counting in triplicate. The sieving of the material reduced significantly the recovery of eggs $(p<0.001)$ and the number of eggs recovered was higher when the sediment was resuspended $(p<0.05)$. After standardization, flotation solutions sodium chloride, zinc sulfate, sodium dichromate, magnesium sulfate, and sodium nitrate $\left(\mathrm{d}=1.20 \mathrm{~g} / \mathrm{cm}^{3}\right)$ were compared. The best results were obtained by using zinc sulfate solution. In conclusion, the chances of recovering T. canis eggs from samples using flotation solutions can be increased by washing of soil twice using distilled water, and resuspension of sediment. On the other hand, the sieving procedure can drastically reduce the number of eggs.
\end{abstract}

KEYWORDS: Toxocara canis eggs; Recovery technique; Soil contamination.

\section{INTRODUCTION}

Human toxocariasis is considered one of the most prevalent helminthiasis in industrialized countries ${ }^{20}$. However, this zoonosis is included in the list of neglected diseases ${ }^{18}$.

Toxocara canis and T. cati are recognized as etiological agents of human disease, worldwide. Their definitive hosts are, respectively, the domestic dog and cat, in which they live as adults within the lumen of the small intestine ${ }^{8}$.

An adult female of Toxocara spp. may produce up to 200,000 eggs per day. Eggs eliminated with feces are not infective and require an incubation period in the soil to embryonate ${ }^{20}$. Infection of human beings is mainly caused by accidental ingestion of embryonated eggs ${ }^{1}$. After ingestion, the infective larvae hatch, penetrate the intestinal wall, migrate through the soft tissues of the body, and may result in either ocular or visceral larva migrans ${ }^{8}$. However, many Toxocara infections remain asymptomatic and therefore remain underdiagnosed and underappreciated ${ }^{34}$.

Human toxocariasis is primarily a soil transmitted zoonosis ${ }^{20}$. Children are the most susceptible group, because of pica habits and regular contact with contaminated sandpit ${ }^{8}$. The high risk places for contamination are especially playgrounds and other public parks. In Brazil, studies performed in several public areas showed contamination rates ranging from $17.5 \%{ }^{29}$ to $91.7 \%$.

The recovery of Toxocara spp. eggs from soil samples vary depending on environmental and climatic conditions, presence of dogs and cats, and soil texture ${ }^{24}$. However, technical factors like the choice of type of solutions, for washing the soil and for flotation, and number of coverslip can also influence the recovery of eggs. Consequently, the lack of standardization of techniques can lead to false-negative results and underestimation of the occurrence of soil contamination, making difficult the comparison of information ${ }^{5}$ and the public health significance of such findings ${ }^{24}$.

In an attempt to evaluate the best technique to recover Toxocara eggs some authors carried out comparative studies among different techniques ${ }^{7,19,24,27,28}$. They compared the techniques as a whole, disregarding the possible interference of variables in each technique.

The purpose of this study was to evaluate the influence of variables on the recovery of eggs of Toxocara canis from soil in controlled conditions using a centrifuge-flotation technique.

(1) Curso de Graduação em Medicina Veterinária e Mestrado em Ciência Animal - Universidade do Oeste Paulista (Unoeste), Presidente Prudente, São Paulo, Brazil.

(2) Bióloga. Mestrado em Ciência Animal. Unoeste.

(3) Curso de Medicina Veterinária/Unoeste.

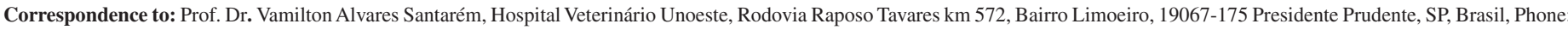
55.18 32292066; FAX: 55.18.32292034.E-mail: vamilton@unoeste.br 
SANTARÉM, V.A.; MAGOTI, L.P. \& SICHIERI, T.D. - Influence of variables on centrifuge-flotation technique for recovery of Toxocara canis eggs from soil. Rev. Inst. Med. trop. S. Paulo, 51(3): 163-167, 2009.

\section{MATERIAL AND METHODS}

Soil samples: Soil samples were submitted to heat sterilization at $150{ }^{\circ} \mathrm{C}$ for $30 \mathrm{~min}$ in a hot air oven, before artificial contamination in order to destroy any contaminating ova ${ }^{22,27}$. The soil was analyzed by the Laboratory of Soil Analysis (Universidade do Oeste Paulista - Unoeste, São Paulo State, Brazil) and was classified according to their composition as sandy.

Eggs of Toxocara canis: Pregnant worms were obtained from puppies kept at the Unoeste Cannel by treatment with Fenbendazole at a dose of $20 \mathrm{mg} / \mathrm{kg}$ body weight. The female worms were washed thoroughly using $0.95 \%$ sodium chloride solution and the anterior one-third of the uterus was dissected. The eggs, obtained from dissection were kept in $0.95 \%$ $\mathrm{NaCl}$ solution, under refrigeration $\left(7^{\circ} \mathrm{C}\right)$ until utilization.

Soil contamination: In order to obtain the exact number of eggs, 20 $\mu \mathrm{L}$ of suspension containing the eggs obtained from dissection of L5 T. canis were placed onto a glass slide and 200 eggs were counted under a microscope (10X power) and transferred to sterile plastic recipients containing one gram of soil. After contamination, the soil was seeded with $480 \mu \mathrm{L}$ of $0.95 \% \mathrm{NaCl}$ in order to maintain the humidity.

The contaminated soil samples were kept under refrigeration $\left(7^{\circ} \mathrm{C}\right)$ for three days before the processing of $T$. canis eggs recovery.

Recovery of eggs (Standard procedure): In order to compare the interference of the variables on the $T$. canis recovery, a technique described previously was employed ${ }^{30}$. Ten milliliters of Tween 80 $0.2 \%(\mathrm{v} / \mathrm{v})$ was added to contaminated soil. The material was filtered through gauze and transferred to a sedimentation apparatus, and was kept overnight at room temperature. The supernatant was discarded and $6.0 \mathrm{~mL}$ of the same anionic detergent was added. The contaminated soil was transferred into $12.0 \mathrm{~mL}$ ground-top centrifuge tubes, that were corked and their contents mixed for 30 minutes using a blood homogenizator at $20 \mathrm{rpm}$ (HS 22-PHOENIX, São Paulo, Brazil) and centrifuged. After discarding the supernatant, $10.0 \mathrm{~mL}$ of a decinormal sodium hydroxide was added, and a wooden stick was used to suspend the sediment. The content of the tubes were mixed for two minutes using a blood homogenizator at $20 \mathrm{rpm}$ and centrifuged. After discarding the supernatant, $10.0 \mathrm{~mL}$ of the flotation solution (sodium nitrate $\mathrm{d}=1.20 \mathrm{~g}$ / $\mathrm{cm}^{3}$ ) was added, the material was resuspended, shaken for two minutes and centrifuged. Immediately after centrifugation process, the tubes were topped up with the same flotation solution, and a coverslip ( 22 X $22 \mathrm{~mm}$ ) placed on the meniscus to collect the floating eggs. Five minutes later, coverslips were removed, placed onto a glass slide and the number of eggs counted under a microscope (10X power).

In order to evaluate the interference of variables, 10 trials for each test were performed. For control, two trials were also performed, using sterilized soil in $500 \mu \mathrm{L}$ of $0.95 \% \mathrm{NaCl}$. The centrifugation process was adopted at $2500 \mathrm{rpm}(679 \mathrm{~g})$ for five minutes for all the tests. The coverslip recovery and count were repeated three times for each tube.

Evaluation of variables: The variables evaluated were: filtration, resting time, washing solutions, time of homogenization, resuspension of sediment, and type and density of flotation solutions.
They were based on the following sequence:

Step 1- Filtering of samples before processing: No filtering X Gauze filtering

Step 2 - Resting time of samples before processing: Overnight X 2 hours

Step 3 - First washing process: Tween 80 0.2\% (v/v) X Distilled water Step 4 - Second washing process: $0.1 \mathrm{~N}$ sodium hydroxide X Distilled water

Step 5 - Number of washing: one time (Distilled water) X twice (Distilled water)

Step 6 - Homogenization time: two minutes X 30 minutes

Step 7 - Resuspension of sample: Resuspension X No resuspension

In order to establish the sequence of comparison, the best, most affordable and accessible material was chosen.

After comparing the steps one to six, and establishing the best material, the standardized technique was used to compare the types of flotation solutions: sodium chloride, zinc sulfate, sodium dichromate, magnesium sulfate, and sodium nitrate $\left(\mathrm{d}=1.20 \mathrm{~g} / \mathrm{cm}^{3}\right)$. Finally, the best two solutions were compared in density $1.20 ; 1.25$ and $1.30 \mathrm{~g} / \mathrm{cm}^{3}$.

Statistical analysis: The Wilcoxon test was used to compare the different steps and the analysis of variance to compare the results between types of flotation solution. When statistically significant ( $p<$ 0.05 ) by ANOVA differences were subsequently analyzed by using the Tukey-Kramer test ${ }^{32}$.

\section{RESULTS}

In this study, it was carried out a step by step comparison in order to compare the influence of variables (filtering, resting time of material, type and solutions for washing, homogenization time, and resuspension of sediment) (Table 1).

In the first step, it was observed that the filtering process interfered negatively, reducing significantly the recovery of $T$. canis eggs when compared to the process in which the material was not filtered $(p<$ 0.0001).

There was no difference in the resting time of soil, overnight and two hours ( $p=0.6523$ ) before the washing process, nor when the distilled water was compared with Tween $800.2 \%(p=0.8764)$ and $\mathrm{NaOH} 0.1$ $\mathrm{N}(p=0.9453)$. A rapid drying up of the material was observed when the $\mathrm{NaOH}$ was used, leading to the rupture of the membrane of egg and the release of its internal material.

It was observed that there was a higher recovery of eggs when the soil was washed twice than when using a unique washing with distilled water $(p=0.0039)$.

There was no difference between the time of homogenization of contaminated soil samples ( $p=0.1934)$. Conversely, the resuspension of sediment improved the recovery of eggs $(p=0.0059)$.

When flotation solutions were compared, zinc sulfate and sodium nitrate showed the best results. However, there was no statistical difference among the solutions, except when zinc sulfate was compared 
Table 1

Toxocara canis eggs recovery (\%) and number (mean \pm standard deviation) in soil samples ( $1 \mathrm{~g}$ ) containing 200 eggs, by using variables in different steps

\begin{tabular}{|c|c|c|c|c|c|}
\hline \multirow[t]{4}{*}{ Step 1} & \multicolumn{4}{|c|}{ Shieving process before washing samples } & \multirow{4}{*}{$\begin{array}{c}p \\
<0.0001 \\
\end{array}$} \\
\hline & \multicolumn{2}{|c|}{ No shieving } & \multicolumn{2}{|c|}{ Shieving } & \\
\hline & Number & Recovery & Number & Recovery & \\
\hline & $25.2 \pm 7.9$ & 12.6 & $2.2 \pm 0.9$ & 1.1 & \\
\hline \multirow[t]{4}{*}{ Step 2} & \multicolumn{4}{|c|}{ Resting time before processing } & \\
\hline & \multicolumn{2}{|c|}{12 hours } & \multicolumn{2}{|c|}{2 hours } & \\
\hline & Number & Recovery & Number & Recovery & $p$ \\
\hline & $22.6 \pm 9.85$ & 11.3 & $20.6 \pm 8.2$ & 10.3 & 0.6523 \\
\hline \multirow[t]{4}{*}{ Step 3} & \multicolumn{4}{|c|}{ Pre-treatment solution } & \\
\hline & \multicolumn{2}{|c|}{ Tween $80(0.2 \%)$} & \multicolumn{2}{|c|}{ Distilled water } & \\
\hline & Number & Recovery & Number & Recovery & $p$ \\
\hline & $13.1 \pm 4.3$ & 6.55 & $12.9 \pm 4.0$ & 6.45 & 0.8764 \\
\hline \multirow[t]{4}{*}{ Step 4} & \multicolumn{4}{|c|}{ Washing solution } & \\
\hline & \multicolumn{2}{|c|}{$\mathrm{NaOH} 0.1 \mathrm{~N}$} & \multicolumn{2}{|c|}{ Distilled water } & \\
\hline & Number & Recovery & Number & Recovery & $p$ \\
\hline & $9.5 \pm 5.9$ & 4.75 & $10.3 \pm 5.5$ & 5.15 & 0.9453 \\
\hline \multirow[t]{4}{*}{ Step 5} & \multicolumn{4}{|c|}{ Number of washing (Distilled water) } & \\
\hline & \multicolumn{2}{|c|}{ One time } & \multicolumn{2}{|c|}{ Twice } & \\
\hline & Number & Recovery & Number & Recovery & $p$ \\
\hline & $14.5 \pm 3.4$ & 7.15 & $8.3 \pm 3.0$ & 4.15 & 0.0039 \\
\hline \multirow[t]{4}{*}{ Step 6} & \multicolumn{4}{|c|}{ Homogenization time (minutes) } & \\
\hline & \multicolumn{2}{|c|}{2} & \multicolumn{2}{|c|}{30} & \\
\hline & Number & Recovery & Number & Recovery & $p$ \\
\hline & $18.9 \pm 7.9$ & 9.45 & $12.5 \pm 5.0$ & 6.25 & 0.1934 \\
\hline \multirow[t]{4}{*}{ Step 7} & \multicolumn{4}{|c|}{ Resuspension of samples } & \\
\hline & \multicolumn{2}{|c|}{ Yes } & \multicolumn{2}{|c|}{ No } & \\
\hline & Number & Recovery & Number & Recovery & $p$ \\
\hline & $14.3 \pm 3.5$ & 7.15 & $8.3 \pm 3.0$ & 4.15 & 0.0059 \\
\hline
\end{tabular}

with sodium chloride (Table 2). There was no difference when the specific densities of zinc sulfate and sodium nitrate were elevated.

According to the results of the technique, the standardization of the technique was as follows: one gram of the soil should be washed twice with $6.0 \mathrm{~mL}$ of distilled water, rest for a period of two hours (or overnight), homogenized, and centrifuged. After discarding the supernatant, the soil should be washed with $10.0 \mathrm{~mL}$ of distilled water, the sediment resuspended, homogenized, and centrifuged. After discarding the supernatant, addition of $12.0 \mathrm{~mL}$ of zinc sulfate solution $(\mathrm{d}=1.20 \mathrm{~g} /$ $\mathrm{cm}^{3}$ ), resuspension of sediment, homogenization, and centrifugation. Homogenization was established for two minutes and centrifugation at 2,500 rpm for five minutes for all the steps.

In this study, eggs were not recovered in the control soil samples.

\section{DISCUSSION}

The recovery of $T$. canis eggs from soil samples varies depending on environmental conditions, choice of sampling sites, presence of dogs and cats, type of soil, and on the type of technique employed for recovery the eggs ${ }^{24}$.

In this study, we observed a recovery ratio of $4.25 \%$, using sodium chloride, to $10.75 \%$ with zinc sulfate. The results can be considered similar to the ones described in the literature. In one of them, the authors found a ratio of 8.0 to $14.8 \%{ }^{17}$. In another experiment, the authors compared six techniques, observing a ratio of 4.8 to $15 \%{ }^{24}$. On the other hand, other researchers obtained a recovery of $67.5 \%$ to $99.91 \%^{28}$. The difference may be explained by the great diversity of modifications adopted by authors in the techniques of centrifuge-flotation. The solution employed for washing, the type and density of the flotation solution, and the number of coverslips were very different in the processing of soil samples. These factors can influence the eggs recovery, making difficult a reliable comparison of the results in the studies on environmental contamination.

The main purpose of our study was to evaluate step by step the influence of variables on the recovery of $T$. canis eggs. It provides further useful information on the improvement of techniques for recovery of ascarids eggs from soil.

The amount of soil used for recovering Toxocara spp. eggs in soil samples is very wide: two $^{21}$, five $\mathrm{e}^{29}$, ten $^{2,23}$, twenty ${ }^{25}$, twenty-five ${ }^{12}$, forty ${ }^{3}$, fifty $^{11,16,24}$, and one-hundred ${ }^{5}$ gram. It is stated that the density of eggs in one gram of naturally contaminated soils are too small to allow confident results, in consequence of the low density of eggs in the sample ${ }^{19}$. In a previous study ${ }^{24}$, six different techniques of centrifuge-flotation, using $50 \mathrm{~g}$ of sand samples contaminated with 10, 100 and 500 eggs were compared. The workers verified that the higher number of recovered eggs was observed in soil containing 500 eggs. However, the best relative efficiency $(\%)$ was observed in samples contaminated with 100 eggs. In

Table 2

Difference between Toxocara canis mean of eggs recovered (\%) and egg number (N) in soil samples (1 g) containing 200 eggs, by using five flotation solutions (SG $\left.1.20 \mathrm{~g} / \mathrm{cm}^{3}\right)$ in centrifuge-flotation technique

Flotation solutions

\begin{tabular}{|c|c|c|c|c|c|c|c|c|c|}
\hline \multicolumn{2}{|c|}{$\mathrm{NaCl}$} & \multicolumn{2}{|c|}{$\mathrm{Na}_{2} \mathrm{Cr}_{2} \mathrm{O}_{4}$} & \multicolumn{2}{|c|}{$\mathrm{Zn}_{2} \mathrm{SO}_{4}$} & \multicolumn{2}{|c|}{$\mathrm{Na}_{2} \mathrm{NO}_{3}$} & \multicolumn{2}{|c|}{$\mathrm{MgSO}_{4}$} \\
\hline $\mathrm{N}$ & $\%$ & $\mathrm{~N}$ & $\%$ & $\mathrm{~N}$ & $\%$ & $\mathrm{~N}$ & $\%$ & $\mathrm{~N}$ & $\%$ \\
\hline $8.5 \mathrm{ab}$ & 4.25 & $14 \mathrm{a}$ & 7.0 & $21.5 \mathrm{ac}$ & 10.75 & $16.0 \mathrm{a}$ & 8.0 & $14.5 \mathrm{a}$ & 7.25 \\
\hline
\end{tabular}

Differences between egg numbers $(\mathrm{N})$ followed by distinct letters $(\mathrm{a}, \mathrm{b}, \mathrm{c})$ indicates statistical significance $(p<0.001) ; \mathrm{NaCl}^{-}$sodium chloride; $\mathrm{Na}_{2} \mathrm{Cr}_{2} \mathrm{O}_{4}-\mathrm{sodium}$ dichromate; $\mathrm{Na}_{2} \mathrm{NO}_{3}$ - sodium nitrate; $\mathrm{MgSO}_{4}$-magnesium sulfate; $\mathrm{Zn}_{2} \mathrm{SO}_{4}$ - zinc sulfate. 


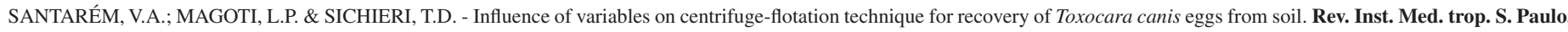
51(3): 163-167, 2009

this study, we adopted one gram of soil because this amount of sample was considered more useful in order to ensure the number of eggs per sample.

Some studies adopted the sieving of soil before processing with a single ${ }^{15}$, a set of different mesh widths ${ }^{21,29}$, or using a coffee sieve ${ }^{3}$. On the other hand, other researchers discard this procedure ${ }^{22,23,25}$. It was observed in the present study that the filtration decreased significantly the number of recovered eggs, contradicting the findings described previously ${ }^{24}$. Probably the gauze used to sieve the sample retained the soil and consequently the eggs stuck on it.

The utilization of anionic detergents, especially Tween was adopted by several workers for washing the soil before processing $2,4,10,11,12,14,19,27,29$. The solution was considered the most efficient for this procedure in soil samples artificially contaminated with $T$. cani $^{25}$. Sodium hydroxide was used in order to promoting the stickiness of eggs ${ }^{13,29}$. Distilled water was used in washing process of soil $1^{3,9,23,33}$. Other authors observed that there was no difference between the use of $\mathrm{NaOH}$ and that of tap water ${ }^{7}$. In our study there was no difference between distilled water and Tween 80 $0.2 \%$ and decinormal sodium hydroxide solutions. Consequently, the use of distilled water is preferable because of its low cost and accessibility in laboratories. It was observed that the recovery of eggs is higher when the process was repeated twice, probably by promoting a higher release of eggs from soil.

There was no difference between the overnight resting time ${ }^{23}$ and the period of two hours before processing of soil samples. Furthermore, the time of homogenization, two or 30 minutes, did not influenced the recovery of eggs. As a result, it could shorten the time of procedure.

As observed previously ${ }^{22}$, the resuspension of soil samples during the flotation technique increases significantly the number of recovered eggs. This procedure was adopted in some studies ${ }^{2,12,13,23,29,31,33}$, but, on the other hand, it was disregarded by some authors $\mathrm{s}^{4,5,10,14,26}$. This exemplifies the variety of techniques that has been used to evaluate the contamination of soil in public places.

Physico-chemical properties of the solutions, such as viscosity, may be as important as the density ${ }^{27}$. In this study, the rates of recovered eggs were higher using zinc sulfate ( specific density $=1.20 \mathrm{~g} / \mathrm{cm}^{3}$ ) and sodium nitrate. It is considered that zinc sulfate $e^{7,19}$ and sodium nitrate ${ }^{24}$ are the best solutions for recovery of Toxocara spp. eggs from soil. However, it was observed in the present study that the latter solution crystallized quickly during examination periods, making the viewing of eggs difficult and drying them up.

In order to improve the recovery of eggs in soil samples diverse authors carried out trials adopting specific gravity higher than 1.20 for flotation solutions: magnesium sulfate ${ }^{5}$, sodium dichromate ${ }^{22,26,29}$, sodium nitrate ${ }^{11,13,31}$, and zinc sulfate ${ }^{15}$. In this study, there were no differences when the solutions were used in different specific gravities of 1.20, 1.25 and $1.30 \mathrm{~g} / \mathrm{cm}^{3}$.

The influence of the type of soil was studied previously ${ }^{22}$. The authors compared four different types of soil, observing that the number of eggs recovered from sand and sandy soils were greater than those recovered from clay silt and silty clay soils. According to them, contaminated samples from sand and sandy soils were more homogeneous, probably because of the greater size of soil particles holding the eggs more loosely. Regarding the type of soil employed in this study, it was classified as sandy with small particles. Consequently, it would enhance the efficiency of the technique.

We observed that the chances of recovering $T$. canis eggs from samples using flotation solutions can be increased by washing of soil twice using distilled water, and resuspension of sediment. On the other hand, the sieving procedure can drastically reduce the number of eggs.

In conclusion, the technique presented in this study can be used for recovery of Toxocara canis eggs as well as of other ascarid eggs from soil, in a reduced time and using accessible and cheapest materials.

\section{RESUMO}

\section{Influência de variáveis na técnica de centrífugo-flutuação para a recuperação de ovos de Toxocara canis em solo}

Com o objetivo de avaliar a influência de variáveis na técnica de centrífugo-flutuação para a recuperação de ovos de Toxocara canis em solo, amostras de solo foram previamente esterilizadas e divididas em alíquotas de um grama e contaminadas com 200 ovos. Após contaminação, foram comparadas, em etapas seriadas, as variáveis: filtragem, tipo de lavagem e ressuspensão do material. Como ponto de partida, utilizou-se técnica com lavagem de solo em Tween $80(0,2 \%)$ e solução de hidróxido de sódio $0,1 \mathrm{~N}$; ressuspensão; e centrífugo-flutuação em solução de nitrato de sódio $\left(\mathrm{d}=1,20 \mathrm{~g} / \mathrm{cm}^{3}\right)$. Os ovos recuperados foram contados com 10 repetições e três leituras para cada repetição. A filtragem reduziu significativamente a recuperação de ovos em relação ao material não filtrado $(p<0,001)$, enquanto o número de ovos foi significativamente maior quando da ressuspensão do material $(p<0,05)$. Após padronização, as soluções de cloreto de sódio, dicromato de sódio, nitrato de sódio, sulfato de zinco, sulfato de magnésio foram comparadas. O sulfato de zinco mostrou os melhores resultados. Dessa forma, as chances de recuperação de ovos de $T$. canis podem ser ampliadas com um processo duplicado de lavagem do solo com água destilada e ressuspensão do sedimento, sendo que a filtragem reduz consideravelmente o número de ovos.

\section{ACKNOWLEDGEMENTS}

To Fundação de Amparo à Pesquisa do Estado de São Paulo (FAPESP) by the fellowship to Tathiana Dias Sichieri (Process number: 07/54.934-3). The authors thank Mr. Christopher Shoebridge for his help in English review.

\section{REFERENCES}

1. ACHA, P. \& SZYFRES, B. - Zoonosis y enfermedades transmissibles al hombre y a los animales. 2. ed. Washington, Organización Panamericana de la Salud, 1986.

2. CAPUANO, D.M. \& ROCHA, G.M. - Environmental contamination by Toxocara sp eggs in Ribeirão Preto, São Paulo, Brazil. Rev. Inst. Med. trop. S. Paulo, 47: 223-226, 2005 .

3. CARDEN, S.M.; MEUSEMANN, R.; WALKER, J. et al.- Toxocara canis: egg presence in Melbourne parks and disease incidence in Victoria. Clin. exp. Ophthalmol., 31: 143-146, 2003. 

51(3): 163-167, 2009.

4. CHILDS, J.E. - The prevalence of Toxocara species ova in backyards and gardens of Baltimore, Maryland. Amer. J. publ. Hlth, 75: 1092-1094, 1985.

5. COELHO, L.M.P.S.; DINI, C.Y.; MILMAN, M.H.S.A. \& OLIVEIRA, S.M. - Toxocara spp. eggs in public squares of Sorocaba, São Paulo State, Brazil. Rev. Inst. Med. trop. S. Paulo, 43: 189-191, 2001

6. CORRÊA, G.L.B.; MICHELON, E.; LAGAGGIO, V.R.A. et al. - Contaminação do solo por ovos, larvas de helmintos e oocistos de protozoários, em praças públicas de Santa Maria e sua importância em saúde pública. Rev. bras. Parasit. vet., 4: 137, 1995.

7. DADA, B.J.O. \& LINDQUIST, W.D. - Studies on flotation techniques for the recovery of helminth eggs from soil and the prevalence of eggs of Toxocara spp in some Kansas public places. J. Amer Vet. med. Ass., 174: 1208-1210, 1979.

8. DESPOMMIER, D. - Toxocariasis: clinical aspects, epidemiology, medical ecology, and molecular aspects. Clin. Microb. Rev., 16: 265-272, 2003.

9. DEVERA, R.; BLANCO, Y.; HERNÁNDEZ, H. \& SIMÕES, D. - Toxocara spp and other helminths in squares and parks of Ciudad Bolívar, Bolivar State (Venezuela). Enferm. infecc. Microb. clin., 26: 23-26, 2008

10. DUBIN, S.; SEGALL, S. \& MARTINDALE, J. - Contamination of soil in two city parks with canine nematode ova including Toxocara canis: a preliminary study. Amer. J. publ. Hlth, 65: 1242-1245, 1975.

11. DUBNÁ, S.; LANGROVÁ, I.; JANKOVSKÁ, I. et al. - Contamination of soil with Toxocara eggs in urban (Prague) and rural areas in the Czech Republic. Vet. Parasit. 144: 81-86, 2007.

12. DUNSMORE, J.D.; THOMPSON, R.C.A. \& BATES, I.A. - Prevalence and survival of Toxocara canis eggs in the urban environment of Perth, Australia. Vet. Parasit., 16: 303-311, 1984.

13. FERREIRA, L.F.M.; OLIVEIRA, E.L. \& CAMILLO-COURA, L. - Sobre a presença de ovos de Toxocara, em praças da cidade do Rio de Janeiro. Rev. Soc. bras. Med. trop., 10: 51-54. 1976.

14. FONROUGE, R.; GUARDIS, M.V.; RADMAN, N.E. \& ARCHELLI, S.M. Contaminación de suelos con huevos de Toxocara sp. en plazas y parques públicos de la ciudad de La Plata. Buenos Aires, Argentina. Bol. chil. Parasit., 55: 83-85, 2000 .

15. GAWOR, J.; BORECKA, A.; ŻARNOWSKA, H.; MARCZYNSKA, M. \& DOBOSZ, S - Environmental and personal risk factors for toxocariasis in children with diagnosed disease in urban and rural areas of central Poland. Vet. Parasit., 155: 217-222, 2008

16. GUIMARÃES, A.M.; ALVES. E.G.L.; REZENDE. G.F. \& RODRIGUES, M.C. - Ovos de Toxocara sp. e larvas de Ancylostoma sp. em praça pública de Lavras, MG, Brasil. Rev. Saúde publ. (S. Paulo), 39: 293-295, 2005.

17. HORN, N.K.; SCHNIEDER, T. \& STOYE, M. - Quantitative vergleich verschiedener methoden zum nachweis der eier von Toxocara canis in sandproben. J. vet. Med., B37: 241-250, 1990.

18. HOTEZ, P.J.; BOTTAZZI, M.E.; FRANCO-PAREDES, C.; AULT, S.K. \& PERIAGO, M.R. - The neglected tropical diseases of Latin America and the Caribbean: a review of disease burden and distribution and a roadmap for control and elimination. PLos Negl. trop. Dis., 2: e300, 2008.
19. KAZAKOS, K.R. - Improved method for recovering ascarid and other helminth eggs from soil associated with epizootics and during survey studies. Amer. J. Vet. Res., 44: 896-900, 1983.

20. MAGNAVAL, J.F.; GLICKMAN, L.T.; DORCHIES, P. \& MORASSIN, B. - Highlights of human toxocariasis. Korean J. Parasit., 39: 1-11, 2001.

21. MATSUO, J. \& NAKASHIO, S. - Prevalence of fecal contamination in sandpits in public parks in Sapporo City, Japan. Vet. Parasit., 128: 115-119, 2005.

22. NUNES, C.M.; SINHORONI, I.L. \& OGASSAWARA, S. - Influence of soil texture in the recovery of Toxocara canis eggs by a flotation method. Vet. Parasit., 53: 269-274, 1994

23. NUNES, C.M.; PENA, F.C.; NEGRELLI, G.B. et al. - Ocorrência de larva migrans na areia de áreas de lazer das escolas municipais de ensino infantil, Araçatuba, SP, Brasil. Rev. Saúde públ. (S. Paulo), 34: 656-658, 2000.

24. OGE, H. \& OGE, S. - Quantitative comparison of various methods for detecting eggs of Toxocara canis in samples of sand. Vet. Parasit., 92: 75-79, 2000.

25. PAQUET-DURAND, I.; HERNÁNDEZ, J.; DOLZ, G. et al. - Prevalence of Toxocara spp., Toxascaris leonina and ancylostomidae in public parks and beaches in different climate zones of Costa Rica. Acta trop., 104: 30-37, 2007.

26. QUEIROZ, M.L.; SIMONSEN, M.; PASCHOALOTTI, M.A. \& CHIEFFI, P.P. Frequency of soil contamination by Toxocara canis eggs in the south region of São Paulo municipality (SP, Brazil) in a 18-month period. Rev. Inst. Med. trop. S. Paulo, 48: 317-319, 2006.

27. QUINN, R.; SMITH, H.V.; BRUCE, R.G. \& GIRDWOOD, R.W.A., - Studies on the incidence of Toxocara and Toxascaris spp. ova in the environment. 1. A comparison of flotation procedures for recovery of Toxocara spp. ova from soil. J. Hyg. (Lond.), 84: $83-89,1980$

28. RUIZ DE YBÁÑEZ, M.R.; GARIJO, M.; GOYENA, M. \& ALONSO, F.D. - Improved methods for recovering eggs of Toxocara canis from soil. J. Helminthol., 74: 349$353,2000$.

29. SANTARÉM, V.A.; SARTOR, I.F. \& BERGAMO, F.M.M. - Contaminação, por ovos de Toxocara sp, de parques e praças públicas de Botucatu, São Paulo, Brasil. Rev. Soc. bras. Med. trop., 31: 529-532, 1998.

30. SANTARÉM, V.A.; FRANCO, E.C.; KOZUKI, F.T.; FINI, D. \& PRESTES-CARNEIRO, L.E. - Enviromental contamination by Toxocara spp. eggs in a rural settlement in Brazil. Rev. Inst. Med. trop. S. Paulo, 50: 279-281, 2008.

31. SHIMIZU, T. - Prevalence of Toxocara eggs in sandpits in Tokushima city and its outskirts. J. Vet. med. Sci., 55: 807-811, 1993.

32. TRIOLA, M.F., ed. - Introdução à estatística. 7. ed. Rio de Janeiro, LTC, 1999.

33. VÁSQUEZ TSUJI, O.; RUIZ HERNÁNDEZ, A.; MARTÍNEZ BARBABOSA, I. et al. Contaminación de suelos por huevos de Toxocara sp. en parques públicos y jardines de casas-habitación de la ciudad de México. Bol. chil. Parasit., 51: 54-58, 1996.

34. WON, K.Y.; KRUSZON-MORAN, D.; SCHANTZ, P.M. \& JONES, J.L. - National seroprevalence and risk factors for zoonotic Toxocara spp. Infection. Amer. J. trop. Med. Hyg., 79: 552-557, 2008.

Received: 26 November 2008

Accepted: 9 March 2009 